\title{
湖水温鉛直分布の季節変動からみた一ノ目潟の水循環機構
}

\author{
草野 由貴子 $* 1 \cdot$ 林 武司 $* 2$

\section{Water circulation in Lake Ichinomegata based on seasonal variation of water temperature profile}

\author{
Yukiko KUSANO*1 and Takeshi HAYASHI*2
}

\begin{abstract}
Lake Ichinomegata, located in the Oga peninsula, Akita Prefecture, is a maar. Since the lake water has been used as water-supply for domestic and irrigation, river water has been conveyed into the lake from autumn to spring in order to replenish the lake water. In this study, processes of thermal stratification, circulation of the lake water, and mixing between the lake water and the conveyed river water were discussed based on seasonal variations of vertical temperature profile observed in the center at the lake. Lake water was thermally stratified from spring to autumn, while water temperature in whole depth was almost homogeneous in lower than $4^{\circ} \mathrm{C}$ during late winter, suggesting that overturn of lake water occurred. Higher wind velocity during winter season was considered as one of factors for overturn. Because the period of ice cover was estimated to not last for long time during winter season, it was suggested that vertical circulation of the lake water was easily caused by strong wind. Therefore, the lake was classified into monomictic lake. River water conveyed into the lake during the period that the lake water was thermally stratified was considered to be stored in the depth shallower than hypolimnion, because the temperature of the river water was higher than that of the hypolimnion. While river water was suggested to be mixed into whole lake water because of overturn in winter season.
\end{abstract}

Key words: Lake Ichinomegata, lake water temperature, thermal stratification, overturn, artificial recharge by water conveyance

I ．はじめに

秋田県男鹿半島の北西部に位置する一ノ目潟・ 二八目潟・三八目潟は，第四紀の火山活動によっ

て形成されたマールである(久野，1955)。これ

ら目潟を含む男鹿半島西部は1973年に国定公園

に指定され，また一ノ目潟は2007年に「男鹿目

潟火山群一ノ目潟」として国の天然記念物に指定

された。これらの指定に基づいて，目潟および周
辺地域の自然の保全がはかられてきた。その一方 で，一ノ目潟の湖水は灌溉用水や水道用水として 利用されており，その水量の確保を目的として, 一八目潟の南方から東方にかけて流れる野村川か らの導水が江戸時代末期から行われている(北浦 一八目潟土地改良区，私信）（Fig. 1）。そのた め, 一八目潟の湖水位は, 用水としての取水打よ び河川水の導水に伴って大きく変動する。後述す るように，本研究期間に打ける水位変化は $7.3 \mathrm{~m}$

*1 東京大学大学院新領域創成科学研究科環境システム学専攻 Department of Environment Systems, Graduate School of Frontier Sciences, The University of Tokyo

* 2 秋田大学教育文化学部 Faculty of Education and Human Studies, Akita University 
に及び，これは水深 $45.1 \mathrm{~m}$ （佐藤ほか，1986） に対して大きな変化量であるといえる。このよう に一ノ目潟は周辺の自然環境が比較的良く保存さ れている一方で, 湖水は従来から取水打よび導水 の影響を受けてきたという点において, 特徴的な 湖沼であるといえる。

湖沼の水温構造や成層・循環による水質形成へ の影響の解明は, 湖沼学・陸水学における主要な 研究テーマの1つであり, 近年では, 地球温暖化 が湖沼の水温分布や水・物質循環機構に与える影 響の評価も重要な課題となっている（永田ほか, 2012)。日本国内の湖沼に打いても, 温暖化に伴 う湖水温の上昇が報告されている(永田ほか, 2012)。例えば, 琵琶湖北湖では1964年から 1997年にかけての湖底付近（水深約 $77 \mathrm{~m}$ ) にお ける水温上昇率は約 $0.041^{\circ} \mathrm{C} /$ 年と算出されてい る(速水・藤原, 1999)。池田湖に打いても, 1985 年から 2000 年にかけての水深 $200 \mathrm{~m}$ の水温 計測の結果から約 $0.03^{\circ} \mathrm{C} /$ 年の水温上昇率が報告 されている(新井, 2009)。

一八目潟に関する湖沼学的・陸水学的研究は, これまでいくつかなされて打り, 古くは夏季にお ける一ノ目潟の水温や溶存酸素, 溶存成分, 生物 群集などの鉛直分布について, 田中（1925）や 吉村（1935）によって報告されている。佐藤ほ か（1986）では, 春季から秋季にかけて, 湖水 温打よび溶存成分組成の季節変化を報告してい る。その結果, 春季から夏季にかけては水温躍層 の形成深度は大きく変化しないが, 夏季から秋季 にかけてはその形成深度が深くなり, 表水層の厚 さが増加していると報告されている。また, 夏季 の水温躍層の温度勾配については, 吉村 (1935) では $10.4^{\circ} \mathrm{C} / \mathrm{m}$ ，佐藤ほか（1986）では $8^{\circ} \mathrm{C} / \mathrm{m}$ が 観測されている。日本国内の湖沼の水温躍層の平 均的な温度勾配は平均 $3 \sim 5^{\circ} \mathrm{C} / \mathrm{m}$ であり, $10^{\circ} \mathrm{C} /$ $\mathrm{m}$ を超えることは稀であることから（吉村, 1937), 一>目潟の水温躍層に打ける温度勾配は 日本国内の湖沼と比較しても大きいといえる。主 要溶存成分組成に関しては, 温度成層する夏季に おいて表水層と深水層では主要溶存成分組成に大
きな差がないことが吉村（1935）により報告さ れており，同様の結果が佐藤ほか（1986）に よっても報告されている。さらに，春季に扑て は風送塩起源と考えられる溶存成分の濃度が上昇 することも報告されている（佐藤ほか，1986）。

しかし, これらの既往研究では冬季の観測が行 われていないため, 湖水の成層・循環機構の周年 変化については明らかにされて抢らず，湖水への 導水の混合機構についても触れられていない。一 八目潟には河川水の導水が行われる点からも, 湖 水の成層・循環機構, および湖水と導水の混合機 構の解明により, 用水としての湖水の水質管理の ための重要な基盤情報を得られることが期待され る。そこで本研究では, 一,目潟の湖水の成層・ 循環機構を明らかにすること，ならびに湖水の成 層・循環に伴う導水と湖水の混合機構を明らかに することを目的とした。

\section{II. 対象地域}

一八目潟は，約 6 万〜 8 万年前にほぼ一回の水 蒸気爆発によって生じたマールであるとされる (青木, 1972)。湖の規模は, 東西幅約 $650 \mathrm{~m}$, 南北幅約 $600 \mathrm{~m}$, 最大水深 $45.1 \mathrm{~m}$ (佐藤ほか, 1986）である。しかし，湖水の取水打よび河川 水の導水によって湖水位は変動する。湖盆は, マールに特有の鍋底状の形状をなしている（奥元 ほか，2007）（Fig. 1）。湖水面の面積は約 $0.26 \mathrm{~km}^{2}$ であり（吉村，1935）, 地形上の集水域 は湖岸を囲んでいる火口壁内に限定され，その面 積は約 $0.79 \mathrm{~km}^{2}$ である。火口壁は湖の西側から 東側に向かって低くなる。東側には谷が形成され ているがこの谷は人工のもので，1855年（安政 2 年）に作られたとされる（田中，1925）。現在 では, この谷に堰が設けられて打り, 湖水の地表 流出はみられない。このように，一ノ目潟は閉塞 湖であるが，季節によって一ノ目潟の南方〜東方 にかけて流れる野村川の河川水が一ノ目潟の南岸 (N1，Fig. 1) より湖内に導水される湖沼である。 一八目潟を起源とする一ノ目潟火山噴出物は, 


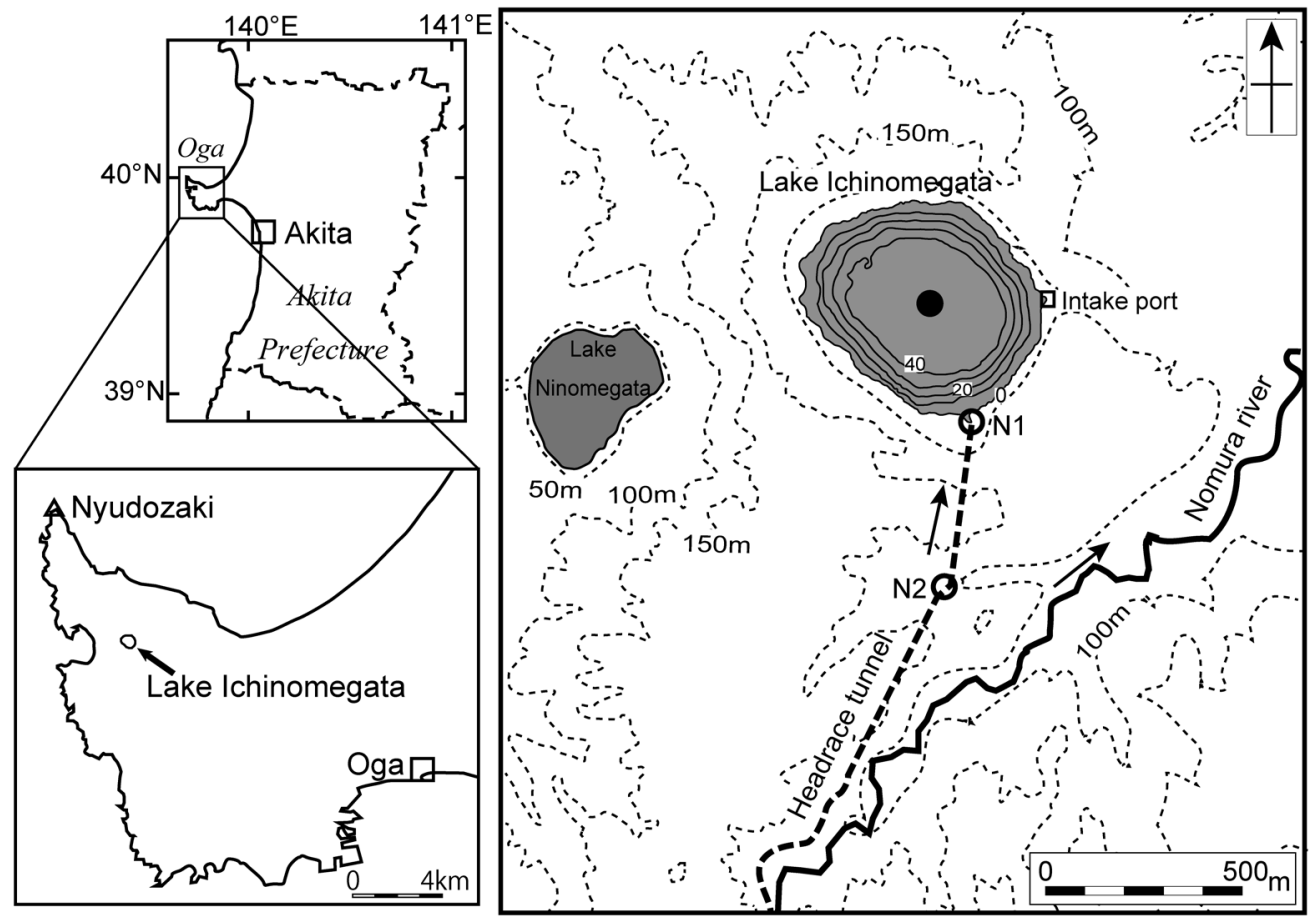

Fig. 1 Location of study area.

Topography is shown by dashed contours. Depth contour (10 m-intervals) of Lake Ichinomegata is shown by solid lines (Okumoto et al., 2007). Measurement points for the lake water and headrace tunnel are shown by solid circle and open circles, respectively. Arrows show flow direction of the Nomura river and the headrace tunnel. An open triangle and open squares in left figures show the location of wind velocity measurement point (Nyudozaki), and these of air temperature measurement points (Akita and Oga), respectively.

粗粒で淘汰の悪い砂砂質の堆積物と，比較的細粒 で葉理や偽層の発達した堆積物より構成される (北村，1990）。このうち砂礫質の堆積物はマー ル形成時の爆発で基盤が破砕されて生じたとみら れる角碩や砂からなるが，これらの他に，安山岩 質の軽石，かんらん石や普通角閃石の団塊も含ま れる（林，1955; 青木，1972）。一ノ目潟の湖岸 壁には中新世の火山岩および堆積岩が露出し（藤 岡，1959）, 火口壁の外側では，一ノ目潟火山噴 出物は主に火口壁の低い南東側に広がっている (北村，1990)。一ノ目潟の東方約 $0.5 \mathrm{~km}$ に位置 する露頭においては，一ノ目潟火山噴出物は厚さ $1.5 \mathrm{~m}$ 程度の三八目潟火山噴出物によって覆われ ているのが観察されている（北村，1990)。ま た，湖底面から湖底面下 $37.8 \mathrm{~m}$ にかけて採取され たボーリングコアによると, 湖底堆積物は主に
泥・砂からなり, 湖底面からの深度 $26.5 \sim 31.7 \mathrm{~m}$ には三ノ目潟火山噴出物が堆積している（秋田 県, 2007)。

一ノ目潟の湖水は，水田の灌溉用水ならびに， 1964年から水道水源としても利用されている。 水道用水 - 灌溉用水の取水は一ノ目潟東岸の取水 口から行われているが (Fig. 1)，それぞれの取 水口は異なった位置にある。両用水の取水口の標 高は湖水位の変動に伴って変化するが, いずれの 時期に扔いても水面下数 $\mathrm{m}$ 程度の深度から取水 されている。本研究の調查期間においては, 灌溉 用水は標高約 $82 \sim 87 \mathrm{~m}$ 程度から, 水道用水は標 高 82 90 m 程度から取水された。一方で，その 水量の確保のため, 毎年一定の期間において野村 川の河川水が導水されており, 一八目潟南岸の導 水流入地点（Fig. 1) の湖水面より湖内に流入す 
る。北浦一ノ目潟土地改良区によると，野村川か らの導水が始まったのは江戸時代末期とされる。 水道水源としての取水は一年を通じて行われる が，灌溉用水としての取水は 5 月～8月に実施さ れ，野村川からの導水は非灌溉期である 9 月〜翌 年 4 月に行われる。したがって，湖水位はこれら の用水利用や導水により，取水量が増加する 5 月 ～8月にかけて低下し，導水が行われる 9 月〜 4 月に上昇する。

\section{III. 調查手法}

筆者らは，2008年 5 月から 2009 年 3 月にかけ て1〜3 ケ月ごとに，一ノ目潟の湖心部において 調查を行った（Fig. 1)。これに加えて，導水路 の湖岸流入部（Fig. 1，N1） 打よび導水路の上流 部（同，N2）においても調查を行った。

湖心部では, 湖上から水温・圧力口ガー （RBR製 TDR-2050，分解能 $0.001^{\circ} \mathrm{C}$ ，精度士 $0.02^{\circ} \mathrm{C}$ ，時定数 0.1 秒）を沈め, 水深 $0 \sim 20 \mathrm{~m}$ ま では $2 \mathrm{~m}$ 間隔で, $20 \mathrm{~m}$ 以深から湖底までは $5 \mathrm{~m}$ 間隔で計測した。各深度では 5 分間以上の時間を かけ，水温センサーが十分に周辺の水温を反映す るまで待ってから，センサーを次の深度に移動さ せた。また，同様の深度から水中ポンプ (大起理 化製 DIK-665A，DIK-666A）を用いて採水を行 い，EC計（横河電機製 $\mathrm{SC} 82 ） に て \mathrm{EC}$ 計測 した。2008年 9 月以降の導水期間中に打いては, 導水（N1，N2地点）についても原則として湖水 と同日に調査を行った。

\section{N. 結果}

\section{1. 湖水位・湖水温の鉛直分布の季節変化}

湖心部に打ける湖水温の鉛直分布の季節变化を Fig. 2 と Fig. 3 に示す。2008年には 4 月末日まで 導水が行われ，5月から灌溉用水の取水が始まり 8月末日まで継続された。これに伴い，湖水位は 2008 年 5 月〜 8 月に $5.5 \mathrm{~m}$ 低下した。9月からは 導水が再開され，2009年 4 月まで継続された。

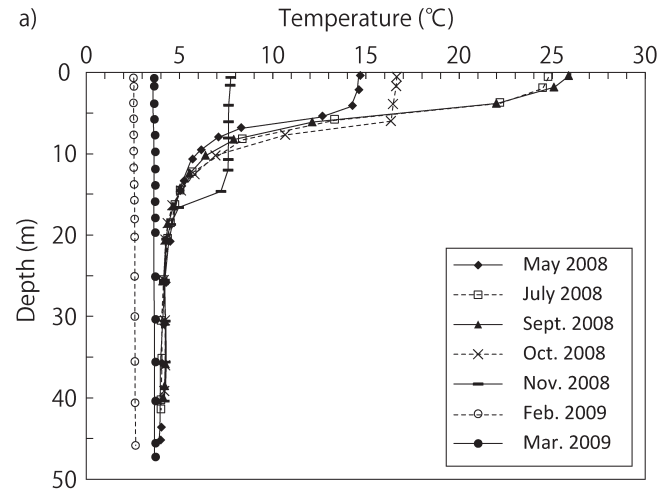

b)

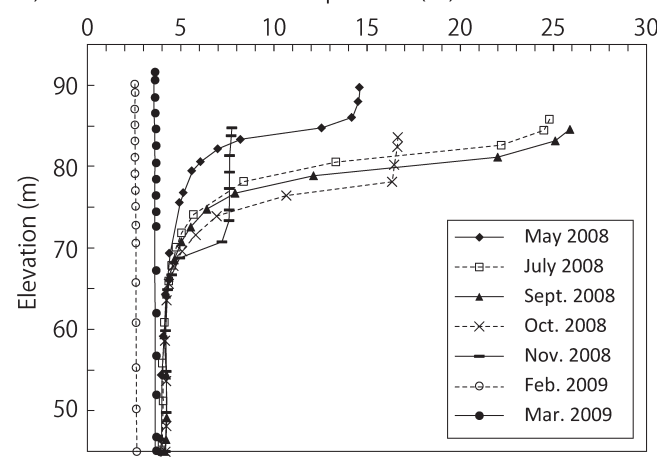

Fig. 2 Seasonal variation of vertical temperature profile measured at the center of Lake Ichinomegata.

Temperature profiles in a) depth from the water surface, and b) elevation are shown.

これにより，湖水位は 2008 年 9 月から 2009 年 3 月にかけて $7.3 \mathrm{~m}$ 上昇した (Fig. 3)。このような 水位変化から，Fig. 2aに湖水面を基準とした水 温の鉛直分布を示すとともに，Fig. $2 \mathrm{~b}$ 打よび Fig. 3では標高を基準とした水温の鉛直分布を示 す。2008年 5 月から 9 月にかけては，気温の上昇 に伴って湖水面から表水層にかけての水温が上昇 し，水温躍層の温度勾配が増加していく様子が認 められた。観測を行った各月における最大の水温 勾配は，5月には湖水面下 $5.5 \mathrm{~m} \sim 6.9 \mathrm{~m}$ に扔いて $3.1^{\circ} \mathrm{C} / \mathrm{m} ， 7$ 月には同 $3.7 \mathrm{~m} \sim 5.8 \mathrm{~m}$ において 4.3 ${ }^{\circ} \mathrm{C} / \mathrm{m} ， 9$ 月には同 $3.8 \mathrm{~m} \sim 6.1 \mathrm{~m}$ において $4.3^{\circ} \mathrm{C} /$ $\mathrm{m}$ を示した。また，水温躍層が形成され始める 深度は 5 月には水深 $6 \mathrm{~m}$ ほどであったが，7月お よび 9 月には水深 $2 \mathrm{~m}$ 以浅であった。

Fig. $2 \mathrm{~b}$ およびFig. 3 をみると，5月から 9 月に 


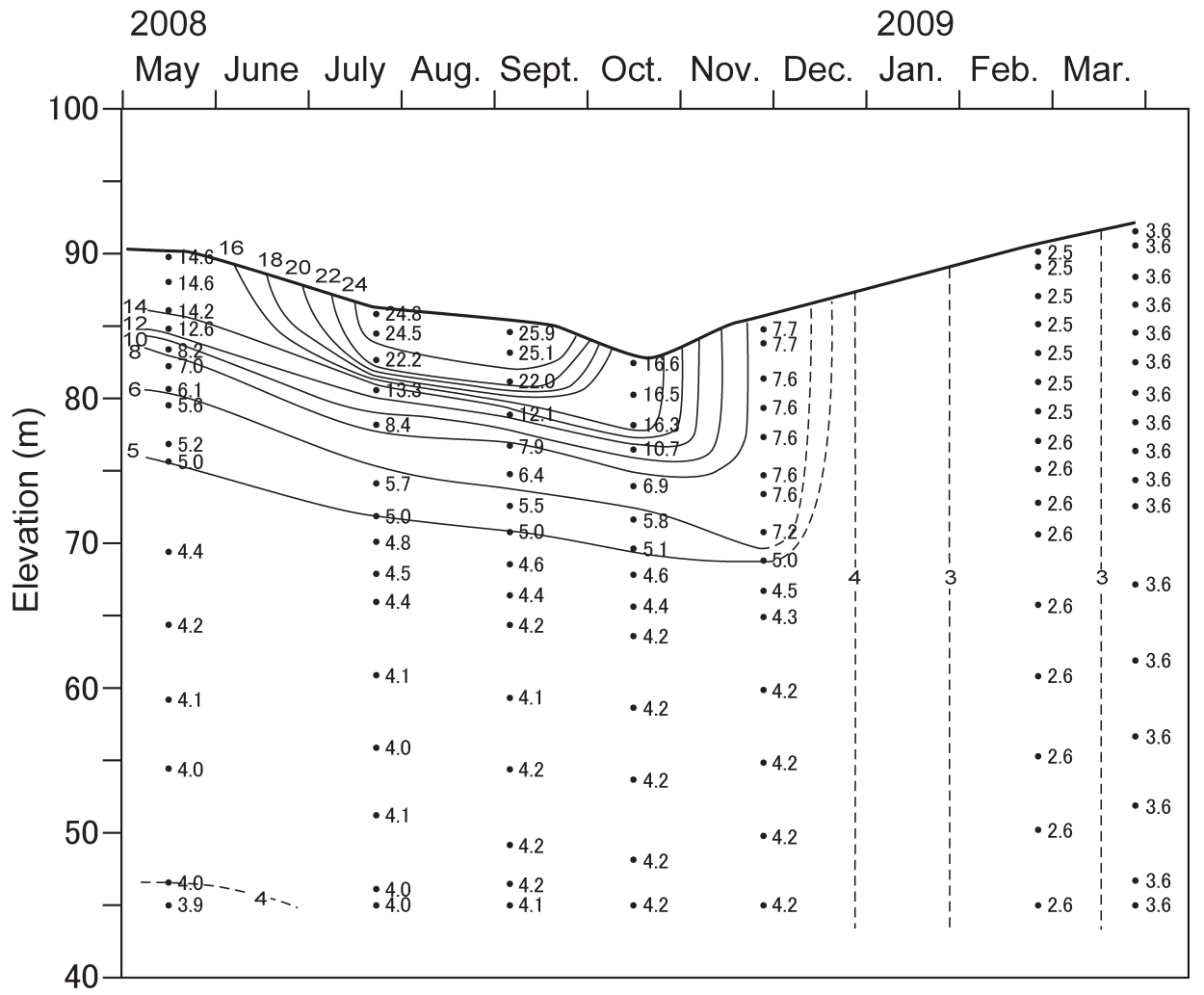

Fig. 3 Annual water temperature distribution of Lake Ichinomegata.

Dots and numbers show elevation and observed temperature, respectively. Solid contours were drawn based on dots, while dashed contours were drawn by estimation from relationship between observed lake water temperature and air temperature shown in Fig. 4.

かけての約 $5.5 \mathrm{~m}$ の湖水位の低下に伴って，水温 躍層が形成される標高は5月から9月にかけて $5 \mathrm{~m}$ ほど低下していた。10月には 9 月よりも湖水 面の水温が約 $9^{\circ} \mathrm{C}$ 低下するとともに，表水層が湖 水面下 $6 \mathrm{~m}$ まで形成され, 水温躍層がそれ以深に 形成されている。しかし，水温躍層以深の水温の 鉛直分布は 9 月と同様であり, 水温躍層が形成さ れる標高にも大きな変化は見られない (Fig. 2b, Fig. 3)。11月には表水層の水温が 10 月よりもさ らに約 $9^{\circ} \mathrm{C}$ 低下するとともに，表水層の厚さは $14 \mathrm{~m}$ に達し, 水温躍層が形成される標高も約 $10 \mathrm{~m}$ 低下した。

Fig. $2 \mathrm{a}$ と Fig. $2 \mathrm{~b}$ を比較すると，5月から 10 月 までの湖水位の低下に伴って水温躍層が形成され る標高が低下していく様子が見られるが（Fig. $2 b)$, 湖水面下からの形成深度に大きな変化は見
られない（Fig. 2a）。また，湖水面を基準とした 湖水温の鉛直分布を比較すると，5月から 10 月 にかけての水温躍層以深の湖水温鉛直分布に大き な変化は見られない。しかし，10月から11月に かけては湖水面を基準とした水温躍層の形成深度 が深くなり，5月〜10月には水温の変化が小さ かった水深約 $10 \mathrm{~m} \sim 15 \mathrm{~m}$ 打いても水温が $2.2^{\circ} \mathrm{C}$ 上昇した（Fig. 2a）。このように，5月から 11 月 にかけては水温躍層が形成され，湖水は水温に よって密度成層していた。また，表水層打よび水 温躍層の形成深度には変動がみられた。

冬季には，2009年 2 月および 3 月には全層の温 度が $4^{\circ} \mathrm{C} よ り も$ 低く，ほぼ均一となった（Fig. 2, Fig. 3)。2月には水深 $15 \mathrm{~m}$ 程度までの水温は 約 $2.5^{\circ} \mathrm{C}$ ，それ以深の水温は約 $2.6^{\circ} \mathrm{C}$ を示して打 り，わずかに水温差が見られた。3月には全層の 
草野・林

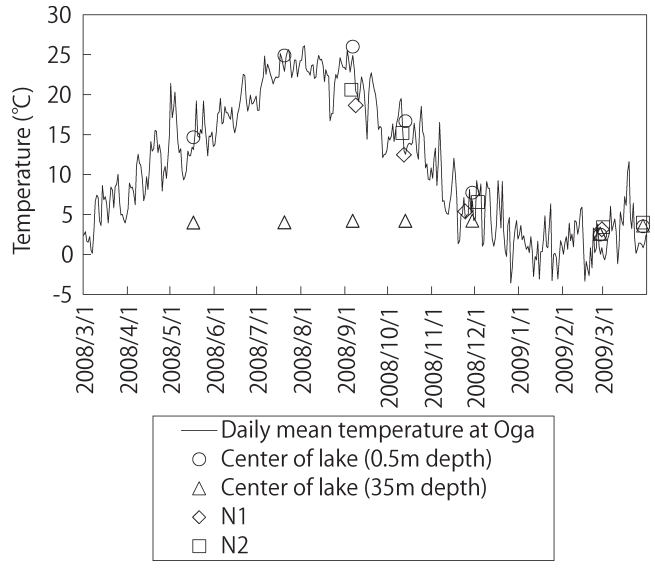

Fig. 4 Seasonal variation of daily mean air temperature at Oga (Japan Meteorological Agency, 2014) and water temperature at the center of the lake (depth: $0.5 \mathrm{~m}$ and $35 \mathrm{~m}), \mathrm{N} 1$, and $\mathrm{N} 2$.

水温が約 $3.6^{\circ} \mathrm{C}$ まで上昇し，水温差は見られな かった。なお, 冬季の湖面の結氷については, 2008 年 12 月から 2009 年 3 月にかけて毎月末に目 視による確認を行い，2009年1月，2月に湖面の 一部に結水が確認された。また 2009 年 2 月 28 日 に水温調査を行った際には，午前中は湖面の一部 が薄く結水していたが午後には氷が溶けてなくな る様子が観察され，3月29日の調查時には結水 は確認されなかった。近隣の気象庁アメダス観測 所である男鹿観測所 $\left(39^{\circ} \mathrm{N} 54.7^{\prime}, 139^{\circ} \mathrm{E} 54.0^{\prime}\right.$, 標高 $20 \mathrm{~m}$ ）に打いては，調査期間中に日平均気 温が 2 日以上にわたって $0^{\circ} \mathrm{C}$ を下回った期間は 5 回あり (Fig. 4)，それらの継続日数は 2 日〜 4 日 であった。これらの結果から，本調査期間におい ては，湖面の結水が長期間継続することはなかっ たと考えられる。

\section{2. 湖水温と導水の水温の比較}

湖心部に打ける水深 $0.5 \mathrm{~m}, 35 \mathrm{~m}$ の水温， $\mathrm{N} 1$, $\mathrm{N} 2$ 地点に打ける導水の水温，気象庁アメダス男 鹿観測所に打ける日平均気温の比較を Fig. 4に示 す。先述のように，水深 $0.5 \mathrm{~m}$ の水温は季節に よって大きく変動したが, Fig. 4から, 水深 $0.5 \mathrm{~m}$ の水温の変動は気温の季節变動と同様であ
ることがわかる。導水の水温も気温と同様の季節 変動を示すが, その変動幅は湖の水深 $0.5 \mathrm{~m}$ にお ける水温変化よりも小さい。導水の水温は, 2008年 9 月から 11 月にかけては水深 $0.5 \mathrm{~m} に$ に ける水温よりも低く, 水深 $35 \mathrm{~m}$ りも高い值を 示した。2009年 2 月，3月には湖水と導水の水温 差は小さくなっている。2009年 2 月に打ける N1

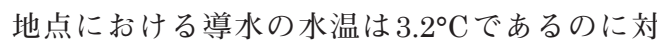
し，湖心部に打ける湖水温は $2.5 \sim 2.6^{\circ} \mathrm{C}$ を示し た。2009年 3 月に打ける N 1 地点での導水の水温 が欠測しているが， $\mathrm{N} 2$ 地点における水温は $4.2^{\circ} \mathrm{C}$ であった。これに対し，3月の湖水温は全層で $3.6^{\circ} \mathrm{C}$ であった。

\section{V. 考察}

\section{1. 湖水の循環機構}

一般に湖水の循環は，湖水面の冷却に伴う対流 だけでなく，風や流入河川などの影響も受ける (ホーン・ゴールドマン，1999）。一ノ目潟では， 導水の流入は $\mathrm{N} 1$ 付近の湖水温の鉛直分布や循環 機構に影響を与えている可能性があるが，本研究 において湖水温の計測を行ったのは湖心部のみで あったため，導水の流入による湖水の循環機構へ の影響を評価することは困難である。以下では， 湖水全体に影響を与えると考えられる気温ならび に風速と，湖水の水温鉛直分布の関係に基づい て，湖水の循環機構について検討を行った。

男鹿半島の北西端に位置し，一ノ目潟から約 $6.2 \mathrm{~km}$ の距離にある海上保安庁入道崎観測所 （Fig. 1）での 2008 年 4 月～2009年 3 月の風速の 観測結果を Fig. 5 に示す。Fig. 5aには日平均值 (点線) ならびに7日間の移動平均値（太線）を， Fig. $5 b$ には月平均值（2008年 4 月～2009年 3 月) を示した。またFig. 5bには，1985年から 2012 年までの風速の月平均值の変動幅も示した。入道 崎での風速データを，そのまま一ノ目潟に適用で きるわけではないが，Fig. 5から，この地域の風 速の季節変動の特徵として, 風速が春季から夏季 に小さく秋季から冬季に大きいことがわかる。 

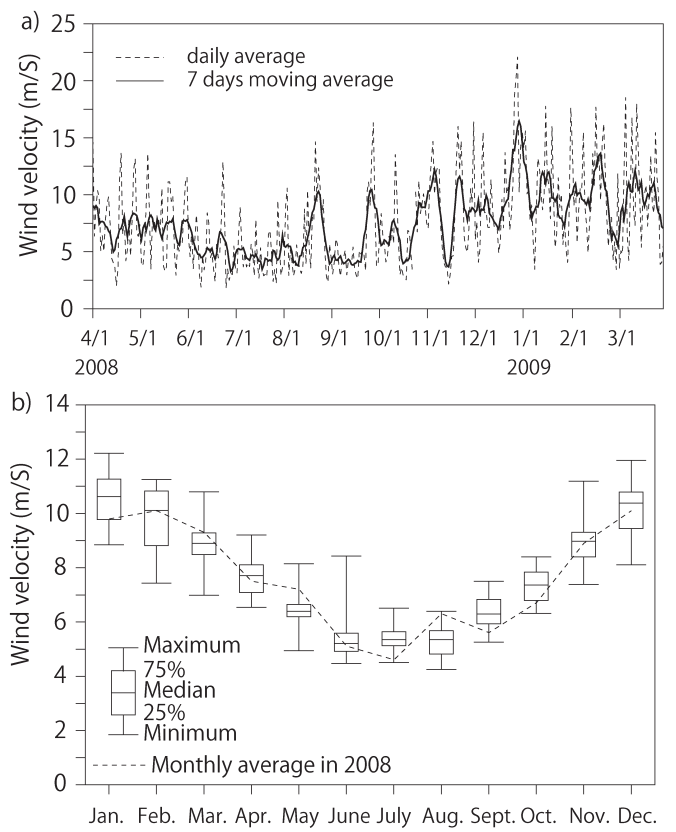

Fig. 5 Wind velocity measured at Nyudozaki (Japan Oceanographic Data Center, 2014).

a) Daily average and moving average of 7 days. b) Monthly average from April 2008 to March 2009 (dotted line) and ranges of monthly mean wind velocity from 1985 to 2012 (box plot). Data in 1977, 2010, and from January to March in 1985 are not included because of lack of observed data.

前章で述べたように 2008 年 5 月から9月にか けては湖水面の水温上昇とともに水温躍層が形成 され始める深度が浅くなり, 水温躍層内の温度勾 配も増加している。Fig. 5より，5月から7月に かけては，日平均風速打よび月平均風速ともに低 下傾向にある。従って，この期間に打いて湖水面 の水温上昇に伴い水温躍層がより浅い深度から形 成された要因の一つとして, 用水としての表層水 の取水および，湖面への風の影響が小さかったた めに表水層内での湖水の鉛直循環が進まなかった こと，が考えられる。

9月から11月にかけては, 湖水面から表水層 にかけての水温の低下とともに水温躍層が形成さ れ始める深度が水深約 $15 \mathrm{~m}$ まで増している。な お，9月以降は，農業用水としての取水は行われ ていない。気温が低下していくとともに（Fig.
4）日平均風速が増加していく（Fig. 5）ことを 考慮すると，表水層の冷却に伴う対流による混合 だけでなく，日平均風速の増加によって表水層内 での湖水の鉛直循環が活発化したため，水温躍層 の形成深度が深くなったと考えられる。

2009 年 2 月には, 水深約 $15 \mathrm{~m}$ （標高 $79 \mathrm{~m}$ 付

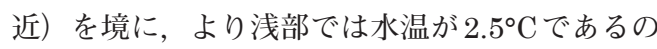
に対し，より深部では $2.6^{\circ} \mathrm{C}$ を示しており，わず かに温度差がみられるものの，水温は全層に打い てほぼ均一となっていた。11月〜2月にかけての 気温の低下に伴い, 表水層内の湖水の冷却が進ん だと考えられるが，表水層の水温と気温の関係 （Fig. 4）を考慮すると, 表水層の水温は 2008年 12 月末頃に $4^{\circ} \mathrm{C}$ まで低下し, 表水層と深水層の 密度差が解消されたと考えられる。また，2008 年 12 月末～ 2009 年 3 月にかけては，一年で最も 風速が大きくなった時期であることが推測される (Fig. 5a)。2008年11月末から 2009年 2 月末まで の期間に全層の水温がほぼ均一に $2.5^{\circ} \mathrm{C} \sim 2.6^{\circ} \mathrm{C}$ まで低下した要因の一つとして, 冬季の強い風の 影響によって強制的な鉛直循環が生じたことで, 湖水面付近で $4^{\circ} \mathrm{C}$ 以下に冷却された（密度の低下 した）湖水と深部の約 $4^{\circ} \mathrm{C} の （$ 密度の大きい）湖 水との混合が進み，全層が $4^{\circ} \mathrm{C}$ 以下までほぼ均一 に低下したことが推測される。

なお，第 IV 章 1 節に述べたように，本調查期間 に扔いては湖面の結水が長期間継続することはな かったと考えられたことや，2月の水温鉛直分布

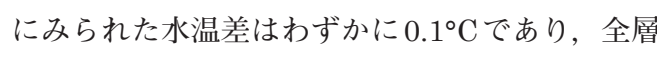
でほぼ均一に冷却が進んだことを併せて考える と，11月末〜2月までの期間において顕著な逆列 成層が長期にわたって形成されていたとは考えに くく，冬季の風の影響により強制的な鉛直循環が 生じやすい期間が継続していたと考えられる。

以上に示したように，本調查期間においては 12 月末〜 2 月および 2 月〜 3 月にかけて全循環が 生じたと考えられたこと，および2月には微小な 水温差が観測されたものの, 冬季において顕著な 逆列成層が形成されていたとは考えにくく，強制 的な鉛直循環が生じやすい期間が継続していたと 
草野・林

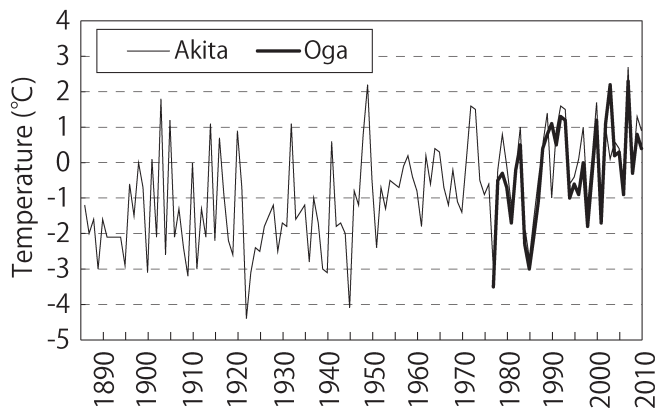

Fig. 6 Variations of average January air temperatures at Akita and Oga (Japan Meteorological Agency, 2014).

考えられることから，本研究期間における一ノ目 潟の循環型は 1 回循環湖に分類できる。冬季にお ける水温の逆列成層が形成されずに全層が $4^{\circ} \mathrm{C}$ 以 下まで冷却された事例は，東北・北海道地方では 支䇗湖 (小関・吉田, 1972)，津軽十二湖湖沼群 の落口の池，中の池（大高ほか，2010）でも報 告されている。

秋田地方気象台打よび気象庁アメダス男鹿観測 所に打ける気温の長期変動（Fig. 6）をみると, 過去には 1 月打ける月平均気温が $0{ }^{\circ} \mathrm{C}$ 以下を示す 年が多くみられ，長期的には上昇傾向にあること がわかる。また Fig. 5bでは冬季の各月の平均風 速の最大值・最小值に大きな差があることが示さ れている。このように年によって気象条件が異な ることから，冬季の結水の頻度や期間の長さ，お よび冬季に打ける風速の大きさや強風の頻度に よって，全循環が生じる期間に差異が生じること や，水温鉛直分布打よびその変化のパターンが異 なることが考えられる。特に，1月に打ける月平 均気温が長期的には上昇傾向にあることから，冬 季に打ける水温の鉛直分布も長期的に変化してき ていることが示唆される。また，本研究では詳細 な検討は行っていないが，気象条件や結水期間の 有無に加えて，導水の流入量およびその水温の長 期的な変動が湖水温の鉛直分布打よび循環機構に 影響を与えることも考えられる。

\section{2. 湖水への導水の混合機構}

一般に湖水の循環は気温の季節变化，風などの
気象条件だけではなく，流入河川の流量，水温等 の影響も受けるとされる。一ノ目潟に打いても, 導水の流入量や水温が少なくとも $\mathrm{N} 1$ 地点付近の 湖水温の鉛直分布に影響を与えることが推測され るが，本研究においては湖心部以外に打ける水温 の鉛直分布の観測を行っておらず，導水の流入量 の季節変化も明らかではないため，導水が湖水の 水温鉛直分布および循環機構に与える影響につい て検討することは容易でない。以下では，湖水温 と導水温の比較，および湖水の成層・循環機構に 関する考察に基づいて，導水の湖水への混合過程 について検討を行う。

導水期間は 2008 年 9 月〜 2009年 3 月であり,

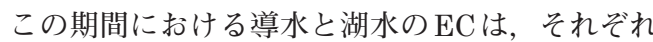
$17.8 \mathrm{mS} / \mathrm{m} \sim 20.6 \mathrm{mS} / \mathrm{m}, \quad 17.2 \mathrm{mS} / \mathrm{m} \sim 17.9 \mathrm{mS} /$ $\mathrm{m}$ であり，大きな差異はみられなかった。また， 導水には懸濁物もほとんど含まれていないことか ら，湖水と導水の密度差は主に水温差に起因する と考えられる。2008年 9 月～11月の密度成層期 には，導水の水温は各月の水温躍層と同程度であ り，深水層の水温よりは高い温度を示している (Fig. 2，Fig. 4)。以上から，2008年 9 月～11月 にかけての導水の密度は深水層の湖水よりも小さ いと考えられ，導水は水温躍層以深には流入しな かったと考えられる。

前述のように，2008年11月～2009年 2 月に全 循環が生じたと考えられたことから，これ以前の期 間に水温躍層以浅に流入した導水，および全循環 が生じている期間中に湖内に流入した導水は，全 循環にともなって湖水に混合されたと考えられる。

一方， 2009 年 2 月に打汀導水の水温は $3.2^{\circ} \mathrm{C}$ であるのに対し，湖心部における湖水温は 2.5 $2.6^{\circ} \mathrm{C}$ を示しており，導水は湖水よりも密度が大 きい。そのため，導水の流入量によっては，導水 は密度流として湖内に流入して密度成層を形成す る場合が考えられる。導水の流入地点 $(\mathrm{N} 1)$ 付 近に打ける湖水温の鉛直分布は明らかではない が，上述のように湖心部における 2 月の湖水温は 標高約 $79 \mathrm{~m}$ （水面下からの深度約 $15 \mathrm{~m}$ ）を境に 深部の水温は $2.6^{\circ} \mathrm{C}$, より浅層の水温は $2.5^{\circ} \mathrm{C}$ を 
示し，わずかな水温差がみられた。この要因とし て, 結水など湖水面の冷却に加え, より水温が高 く, 密度の大きい導水が深層に流入した（9月か らの湖面標高の上昇量は $7.3 \mathrm{~m})$ ことによって, 深層においてわずかに高い温度を示した可能性も 考えられる。

2009 年 3 月に打ける N1地点での導水の水温が 久測しているが, 導水路の上流部 (Fig. 1中の $\mathrm{N} 2 ） に お け る$ 水温は $4.2^{\circ} \mathrm{C}$ を示している。いず れの時期においてもN1ではN 2 よりも低い水温 を示す傾向にあり，冬季である2008年11月〜 2009 年 2 月に観測された N1と N2の水温差は $0.25 \sim 1.13^{\circ} \mathrm{C}$ であったことから，2009年 3 月に 打いても, $\mathrm{N} 1$ の水温は $\mathrm{N} 2$ よりも $0.2 \sim 1^{\circ} \mathrm{C}$ 程度 低い水温，すなわち約 $3 \sim 4^{\circ} \mathrm{C}$ であったと推定さ れる。 3 月に打ける全層の湖水は $3.6^{\circ} \mathrm{C}$ であり, $\mathrm{N} 1$ 地点から流入する導水の水温によっては, 湖 水と導水の間に密度差が生じたと考えられるが, 湖心部の水温は全層で均一であり，この期間にお ける水温の異なる導水の流入によって湖水が成層 していた様子は見られない。また，2009年 2 月〜 3月にかけても全循環が生じたと考えられたこと からも，この期間中に湖内に流入した湖水は全循 環に伴って全層の湖水に混合されたと考えられる。

な打，湖内に流入した導水が湖水温の鉛直分布 にどのような影響を与えるかについて検討するに は，湖心部だけでなく $\mathrm{N} 1$ 付近を含む湖内の複数 地点に打いて水温の計測を行う必要がある。ま た，密度成層している期間に流入した導水が，水 温躍層以浅に打いて水平方向にどの範囲までの湖 水と混合されるか, 湖水の全循環によって導水が 湖水と均一に混合されるかについては, 導水の流 入量の計測および湖内の複数地点に打ける湖水の 水温, 水質, 同位体組成などの鉛直分布の計測に より, 湖水に対する導水の混合過程について検討 を行う必要がある。

\section{V. まとめ}

本研究では，男鹿半島の北西に位置するマール
である一ノ目潟において，年間を通じて湖水温の 鉛直分布を調査し，冬季の温度分布を初めて明ら かにした。湖水温鉛直分布の季節変化や導水の水 温・ECの季節変動の観測結果とともに, 海上保 安庁入道崎観測所における風速データを参照し て, 湖水の成層・循環機構ならびに湖水の成層・ 循環に伴う導水の湖水への混合機構について検討 した。

本研究で明らかとなった, 冬季における一ノ目 潟の湖水温鉛直分布の特徵として, 湖水の全層が $4^{\circ} \mathrm{C}$ 未満まで低下し得ることが挙げられる。本研 究の観測期間では，2月に $2.5 \sim 2.6^{\circ} \mathrm{C}$ まで低下し ていた。このような温度分布の成因として, 以下 に示す循環機構が考えられた。

一八目潟では，春季から秋季にかけては水温に よる成層構造を有し, 水温差によって密度成層し ている。一方，冬季には全層の水温がほぼ均一と なって密度差が解消されていたことより, 全循環 が生じたと考えられた。また，冬季の強風が全循 環を引き起こす要因の一つとなっていることが推 測された。本研究の観測期間に打いては，冬季は 年間で最も風速が大きい時期であることが推測さ れたことや，また湖面の結水期間が短く顕著な水 温の逆列成層が形成されていたとは考えにくいこ とから，冬季に打いては強制的な鉛直循環が生じ やすい期間が継続していたと考えられ，本研究期 間に打ける一ノ目潟の循環型は 1 回循環湖に分類 された。また，湖水が水温によって成層している 時期に湖内に流入した導水は湖水全体に混合され ずに温度躍層より浅部に貯留されるが，全循環が 生じることで全層の湖水と混合されると考えられ た。

長期的にみると，秋田地方気象台における 1 月 の月平均気温は上昇傾向にあり (Fig. 6), 今後 も冬季の気温上昇が継続することで冬季の表水層 の水温が $4^{\circ} \mathrm{C}$ まで冷却されない場合には, 冬季の 循環が深水層まで達しないことが予想される。そ のような循環機構が長期間維持されれば，深水層 の水温分布にも影響が表れることが推測される。 さらに，温暖化による気候変動に伴って流入する 
導水の水温や流量が長期的に変化することによっ ても, 湖水の循環機構に影響を与える可能性があ る。湖水の利用および湖沼環境の保全のために は, 湖水の循環機構ならびに導水との混合機構を 明らかにすることに加えて, 気候変動に伴う湖水 および導水の物理・化学性状や導水の流量の長期 的な変化も把握・評価していく必要がある。今 後，導水の流入量や湖水打よび導水の水質・同位 体組成と水温の観測結果を併せて検討すること で，より詳細な循環・混合機構を解明できると期 待される。

\section{謝辞}

本研究を進めるにあたり, 北浦一ノ目潟土地改 良区，男鹿市企業局水道工務課，秋田県自然保護 課自然公園班より貴重な資料をご提供いただきま した。また, 本論文の作成に当たり 2 名の匿名査 読者より有益なコメントを頂きました。ここに記 して深く感謝申し上げます。

\section{参考文献}

青木謙一郎（1972）：マントルからきた物質一一 の目潟火山の噴出物一. 科学, $42(11), 615-$ 621.

秋田県（2007）：環境資源のワイズユースによる 地域コミュニティの再生と持続可能な地域づく りに関する調査研究報告書， 77-93.

新井 正 (2009)：気候変動と陸水の温度および 水況の変化. 陸水学雑誌, 70 (2), 99-116. アレキサンダー, J, ホーン・チャールス, R, ゴールドマン著, 手塚泰彦訳 (1999)：陸水学 (原著第 2 版). 京都大学学術出版会, $638 \mathrm{p}$. 大高明史 - 神山智行 - 長尾文孝 $\cdot$ 工藤貴史 - 小笠 原嵩輝・井上栄壮 (2010) : 津軽十二湖湖沼 群・越口の池湖群に打ける湖水循環と底生成物 の深度分布. 陸水学雑誌, 71(2), 113-127.

奥元か抢り・原口 強・吉永佑一 (2007) : 音波 探査による湖底地質構造の三次元化一秋田県一
の目潟を例として一. 日本応用地質学会平成 19年度研究発表会講演論文集, 189-190.

気象庁 (2014)：過去の気象データ検索. http:// www.data.jma.go.jp/obd/stats/etrn/index. php，2014年 1 月 20 日参照.

北村 繁（1990）：男鹿半島目潟の形成年代. 東 北地理，42(3)，161-167.

久野 久 (1955) : 火山扩よび火山岩. 岩波書 店, $255 \mathrm{p}$.

小関迪子・吉田順五（1972）：支笏湖俱多楽湖の 水温鉛直分布. 低温科学. 物理篇. 資料集, 29, 1-14.

佐藤典人 · 船山幸夫 ·佐藤正史 - 吉田武則 （1986）: 男鹿半島目潟に関する二, 三の湖沼学 的知見. 東北地理, $38(2), 143-153$.

田中阿歌麿 (1925) : 男鹿半島の湖沼研究紀行. 地理教育， 2，422-430.

永田 俊 - 熊谷道夫 · 吉山浩平 (2012) : 温暖化 の湖沼学. 京都大学学術出版会, $289 \mathrm{p}$.

日本海洋データセンター (2014) : 沿岸海上気象 データ検索. http://jdoss1.jodc.go.jp/cgi-bin/ 2001/wave.jp，2014年1月 20 日参照.

林 宏 (1955) : 秋田県男鹿半島一の目潟周辺の 火山放出物について。地質学雑誌, 61 (717), 240-248.

速水祐一・藤原建紀 (1999) : 琵琶湖深層水の温 暖化. 海の研究, 8(3), 197-202.

藤岡一男 (1959)：5万分の1地質図幅「戸賀 船川」, 同説明書. 地質調査所, $61 \mathrm{p}$.

吉村信吉 (1935) : 男鹿半島三火口湖の湖沼学的 予察研究. 地理学評論, 11 (10), 872-892. 吉村信吉 (1937)：湖沼学 (増補版). 産業技術 センター, 439 p.

(原稿受付 : 2014 年 3 月 17 日) (原稿受理：2015年1月 13 日)

この論文に対する「討論」を 2015 年 8 月 31 日 まで受け付けます。 


\title{
湖水温鉛直分布の季節変動からみたーノ目潟の水循環機構
}

\section{草野 由貴子・林 武司}

\begin{abstract}
要旨
秋田県男鹿半島に位置する火口湖である一ノ目潟の湖水は，灌溉用水および水 道水として利用されて打り，その水量の確保のために，秋季から春季にかけて河 川水が導水されている。本研究では，一八目潟の湖水の停滞・循環機構ならびに 導水との混合機構を明らかにすることを目的として，湖水温の鉛直分布の季節変 動を把握した。湖水は, 春季から秋季にかけて水温による密度成層が形成されて いたが，晚冬季には全層の水温は $4^{\circ} \mathrm{C}$ 以下でほぼ均一となり，水温による密度差 が解消されていたことより，全循環が生じたと考えられた。また，冬季の強風が 全循環を引き起こす要因の一つとなっていることが推測された。本研究期間の冬 季においては結水の期間が数日程度と短かったことが推測され，湖水は風による 鉛直混合の影響を受けやすい状態が継続されたと考えられた。そのため，本研究 期間における一ノ目潟の循環型は 1 回循環湖であるといえる。また，水温によっ て成層が形成されている期間に湖内に流入した導水は湖水全体に混合されずに温 度躍層より浅部に貯留されるが，冬季に湖水の全循環が生じることで湖水と導水 が混合されると考えられた。
\end{abstract}

キーワード：一ノ目潟，湖水温，温度成層，全循環，導水涵養 